\title{
Technique de cuisson dans un four enterré : la pachamanca des Andes du Pérou
}

Isabelle Carlier

\section{(2) OpenEdition}

12 Journals

Édition électronique

URL : https://journals.openedition.org/tc/665

DOI : $10.4000 /$ tc. 665

ISSN : 1952-420X

Éditeur

Éditions de l'EHESS

\section{Édition imprimée}

Date de publication : 1 mai 1993

ISSN : 0248-6016

\section{Référence électronique}

Isabelle Carlier, «Technique de cuisson dans un four enterré : la pachamanca des Andes du Pérou », Techniques \& Culture [En ligne], 19 | 1993, mis en ligne le 10 janvier 2006, consulté le 29 septembre 2022. URL : http://journals.openedition.org/tc/665 ; DOI : https://doi.org/10.4000/tc.665

Ce document a été généré automatiquement le 29 septembre 2022.

Tous droits réservés 


\section{Technique de cuisson dans un four enterré : la pachamanca des Andes du Pérou}

Isabelle Carlier 